\title{
Gender and small-scale fisheries in Brazil: insights for a sustainable development agenda
}

\author{
Mariana Martins de Andrade ${ }^{1, *}$, Luciana Yokoyama Xavier ${ }^{1,2}$, Natalia de Miranda Grilli1 ${ }^{\oplus}$, \\ Carina Costa de Oliveira ${ }^{1,3}$, Denise Almeida de Andrade ${ }^{4}{ }^{\oplus}$, Giovanna C. Barreto ${ }^{5} \odot$, Luceni Hellebrandt ${ }^{6} \oplus$, Melina \\ Chiba Galvão ${ }^{70}$, Solange Teles da Silva ${ }^{1,8}$, Tarin Cristino Frota Mont'Alverne ${ }^{9}$, Leandra Regina Gonçalves ${ }^{1,2,10}$

\footnotetext{
${ }^{1}$ Liga das Mulheres pelo Oceano

${ }^{2}$ Instituto Oceanográfico da Universidade de São Paulo (Praça do Oceanografico, 191 - Cidade Universitária - São Paulo - 05508-120 - SP - Brazil)

${ }^{3}$ Universidade de Brasília - Faculdade de Direito - Grupo de Estudos em Direito,Recursos Naturais e Sustentabilidade (Gern-UnB). (Campus Universitário Darcy Ribeiro - Asa Norte - Brasília - 70904-970 - DF - Brazil)

${ }^{4}$ Centro Universitário Christus - Campus Parque Ecológico (Rua Adolfo Gurgel, 133 - 3․ andar - Fortaleza - 60190-180 - Brazil)

${ }^{5}$ Universidade Federal do Paraná (R. dos Funcionários, 1540 - Cabral - Curitiba - 82590-300 - PR - Brazil)

${ }^{6}$ Universidade Federal do Rio Grande - Laboratório Interdisciplinar MAReSS - (Av. Mal. Floriano Peixoto, 2236 - São Lourenço do Sul 96170-000 - RS - Brazil)

${ }^{7}$ Instituto Federal de Santa Catarina - Campus Itajaí (Av. Ver. Abrahão João Francisco, 3899 - Ressacada - Itajaí - $88307-303$ - SC - Brazil)

${ }^{8}$ Universidade Presbiteriana Mackenzie - Faculdade de Direito (Rua da Consolação, 896 PPGDPE - São Paulo - $01302-907$ - SP - Brazil)

${ }^{9}$ Universidade Federal do Ceará - Faculdade de Direito (R. Meton de Alencar, s/n - Centro - Fortaleza - 60035-160 - CE - Brazil)

${ }^{10}$ Universidade Federal do Estado de São Paulo - Instituto do Mar (Rua Silva Jardim, n 136 - Santos - 11015-020 - SP - Brazil)

*Corresponding author: mariana.martinsdeandrade@gmail.com
}

\section{ABSTRACT}

The role of women in the fisheries sector is largely underestimated and underreported. Although women are a fundamental part of the seafood supply chain in Brazil, fisheries management is gender-biased; sectoral programs and policies fail to recognize, support, and guarantee fisherwomen legal and labor rights. Brazilian fisherwomen have been very active in claiming their rights and recognition in the fisheries sector; however, public policies are lagging, and so are the studies that subsidize them. Within the UN Decade of Ocean Science for Sustainable Development and 2030 Agenda, it is critical to analyze the interactions between SDG 14 (Life below water) and SDG 5 (Gender equality) to discuss the gender dimensions underpinning fisheries (un)sustainability. We performed a systematic literature review and bibliometric analysis of gender-oriented studies in marine fisheries in Brazil. We identified 19 studies, published up to December 2020, focused on artisanal fisheries. The publications show that women are present in fisheries and are fundamental subjects to maintaining the activity and continuity of this livelihood. However, fisherwomen remain invisible. Their work is underreported, underpaid, and undervalued, which jeopardizes the sustainability of artisanal marine fisheries. Considering the knowledge gaps to be addressed during the Ocean Decade, we recommend that researchers and politicians work to: make "hidden workforce" of women visible, embrace interdisciplinarity, set research priorities, fill the data gap, and subsidize public policies. During the next few years, it is critical to enable and settle monitoring and assessment programs that provide open access to data, information, and technologies for the predictability, the sustainable harvesting of the ocean, and the correct design of gender-sensitive fisheries and aquaculture policies.

Descriptors: Fisheries, Gender equality, Ocean decade, Sustainability, Agenda 2030.

Submitted: 19-Apr-2021

Approved: $16-$ Oct-2021

Editor: Rubens M. Lopes

(c) 2021 The authors. This is an open access article distributed under the terms of the Creative Commons license.

\section{INTRODUCTION}

Fisheries make significant contributions to the lives of millions of people worldwide as it serves as a 
source of food, nutrition, income, and tradition, providing some of the most traded food commodities in the world (FAO, 2020). Small-scale fisheries usually takes place in communities, fused with local livelihoods (FAO, 2015). Many small-scale fisheries workers are self-employed and provide fishing resources for direct consumption within their households (FAO, 2020). Women are significant participants in the fishery sector, particularly in postharvest and processing activities (FAO, 2020). However, the definition of "fishery" often excludes these activities, hampering women's access to rights, subsidies, and means of production.

Even though women's roles are linked to the promotion of food security (Harper et al., 2013) and sustainable livelihoods (Kleiber et al., 2015), cultural taboos and practices lead to gender-based labor divisions, rendering much of women's work in fisheries invisible and in underpaid or unpaid positions (Di Ciommo and Schiavetti, 2012; Freitas et al. 2020; Bennett 2005; Choo et al. 2008).

Although there is evidence that gender analysis fosters scientific discovery, improves experimental efficiency, and enables social equality (Tannenbaum et al., 2019), gender aspects in marine science have often been overlooked. Gender equality approaches in fisheries research are still incipient (Barreto et al., 2020; Freitas et al., 2020), and fishing studies usually describe it as a male activity (Rohe et al., 2018). In a systematic literature review, Barreto et al. (2020) identified thirty-five human dimensions components cited in marine studies (including fisheries), of which gender was the least cited (appeared in only 4 out of 92 articles).

The Voluntary Guidelines for Securing Sustainable Small-Scale Fisheries in the Context of Food Security and Poverty Eradication was the first and foremost to recognize the need to discuss and consider gender equality in the future of responsible fisheries (FAO, 2015 p.59). But, the implementation of such an approach is a critical step (Kleiber et al., 2017), because fishing research still overlooks gender aspects in policy, economic and societal benefits (Chuenpagdee et al. 2006; Harper et al. 2013; Gustavsson and Ridley, 2018).

In Brazil, the National Policy for the Sustainable Development of Aquaculture and Fisheries (Law 11,
959 of 2009) includes activities usually performed by women, such as processing fishing products, in the definition of small-scale fisheries. It addresses the importance of households and communities in maintaining the artisanal fisheries' livelihoods and their relationship with the ocean in economic, social, and human dimensions (Kleiber et al., 2015). However, the same Law conceptualizes fish workers only as those engaged in the capture stage of fisheries. In 2015, the Federal Decree 8,425 recognized fisherwomen as subjects and beneficiaries of fisheries activities and fishing product processing as part of the productive chain. However, in 2017, Federal Decree 8,967 excluded these activities as part of the artisanal fishing activity.

Relevant publications from the 1970s and 1990s in various regions of Brazil focused chiefly on women's participation in fisheries in continental waters and rivers (Alencar, 1991; Motta-Maués, 1999). More recently, a gender-focused point of view is becoming common in Brazilian studies from different knowledge fields (e.g., Kleiber et al., 2015; Freitas et al., 2020; Galvão et al., 2020; Silva et al., 2020), and studies are growing in number. This advance upholds gender and fisheries research as an opportunity to foster interdisciplinarity, considering the great diversity of issues, approaches, and contexts (Kleiber et al., 2015).

Conducting interdisciplinary research focusing on gender equality in fisheries provides the opportunity to integrate the Sustainable Development Goals (SDGs) of the 2030 Agenda and contribute to implementing the United Nations Decade of Ocean Science for Sustainable Development 20212030 (Ocean Decade). The SDGs grow upon the motto of "leave no one behind", and can mobilize the ocean community to discuss important issues and ideas towards the protection and sustainable use of the ocean in a broad sense during this decade (Ryabini et al., 2019). Likewise, it is argued that the ocean can be understood as a stage that connects all of the 17 SDGs (Le Blanc et al., 2017). Although the interactions of marine resources and livelihoods, such as fisheries, make sense in a holistic context and cross-cutting agenda (Kleiber et al., 2015; Claudet et al., 2020), the direct link with gender issues is still underexplored. 
Improving gender equality in fisheries (i.e., when women are fairly recognized and paid and actively participate in decision-making processes) benefits women and the community, the environment, and the activity itself ( $\mathrm{Di}$ Ciommo and Schiavetti, 2012; Freitas et al. 2020). When women do not have the decision-making power to manage community resources, this deprives their access to income (Bennet, 2005). Financial gain controlled by women benefits childcare and healthy conditions, such as through food and education (Hansford, 2016; Wouterse, 2016) more than when controlled by men (Ward-Batts, 2008). When women engage in natural resource management processes, there is an improvement in collaboration, solidarity, conflict resolution, long term views of and a holistic approach to management issues, compliance rules, and capacity of self-sustaining collective action (Agarwal, 2009; Staples; Natcher, 2015; Westermann et al., 2005). These are essential skills and capacities for sustainability performance (Plummer et al., 2012).

In this research, we want to highlight the specificity and the interdependence of SDGs 5 (Gender Equality) and 14 (Life below water) to disrupt the notion of gender-blind fisheries. We recognize that gender issues related to the ocean go far beyond the fishing sector (Verma, 2018) and women-focused discussions. As fisheries are at the center of the ocean economy and its development, understanding gender dimensions of fisheries is key to advancing the sustainable and equitable approach that SDG 14 and the Ocean Decade intend to foster.

\section{METHODS}

We performed a systematic literature review by surveying the databases of Repomar (Brazilian Marine Sciences depository), Catálogo de Teses \& Dissertações CAPES, Web of Science, and Scielo. Although some of these platforms entail redundancy, they assess grey literature (i.e., theses and dissertations), an essential component of the present survey given the limited coverage of this topic in the primary literature. We opted for including major Brazilian databases to understand whether the publications are academic products of local scope or articles of international projection. We designed a multiple-step survey and analysis framework (Figure 1) based on inclusion and exclusion criteria for Brazilian publications on gender and fisheries with a focus on women. This search considered all publications available up to December 2020.

In step 1, we performed a boolean search for the terms "gender," "fisheries", "women", and "Brazil" (in English and Portuguese). In step 2, all abstracts, titles, and keywords were read; studies that did not mention gender or the role of women in fisheries and did not have a Brazilian study area were excluded. In this step, we have also excluded studies about fisheries and gender in continental waters and rivers. Studies regarding estuarine and coastal regions were considered in the following steps.

In step 3, the abstracts were again read to select studies in which gender concerns or points of view were the main topics of the research. In the next step, we also identified the issues and themes covered by the studies to support categorization into groups. In step 4, all studies available were read in their entirety and classified into thematic categories (Table 1) according to their subject matter. These categories were based on the studies themselves. Considering that many studies could present interfaces with more than one category, each one was categorized in all possible topics.

In step 5, the studies filtered were analyzed regarding their source (i.e., Repomar; Catálogo de Teses \& Dissertações CAPES; Web of Science; Scielo); authorship (i.e., gender of the leading author); region of the study area in Brazil (i.e., north, northeast, southeast, south); year of publication; language (i.e., Portuguese; English); and type of publication (i.e., research papers, thesis or dissertations). For thesis and dissertations, the institution's location in Brazil (i.e., north, northeast, southeast, south) and the academic field (i.e., focused on social, natural, and interdisciplinary science) were also considered. For research papers, we assessed the region of the academic institution (i.e., north, northeast, southeast, south) in which the leading authors are affiliated and the scope of the journal.

The results from the bibliographic search are not exhaustive, being limited by the databases and the criteria applied for the search. The categories used to classify the publications are exploratory and illustrative of the role of women in fisheries in Brazil. 
(1) Step: boolean search
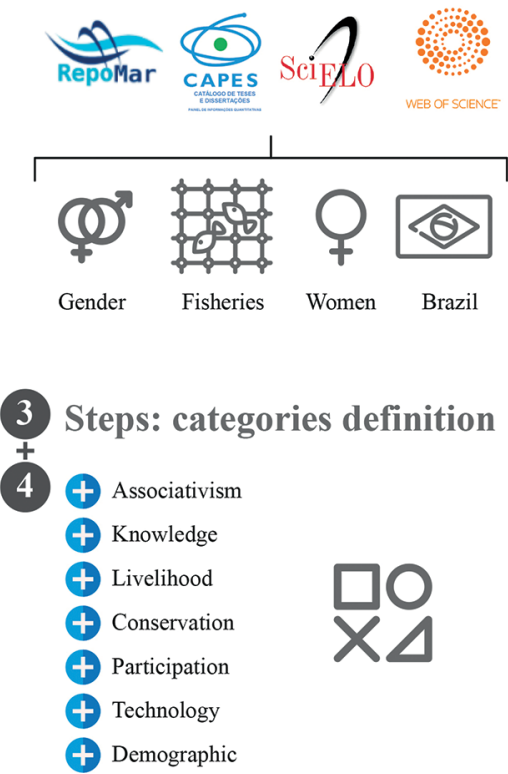

2 Step: analytical reading abstract, title and keywords

(v) Gender
v Brazil
v Women and fisheries
v Continental waters

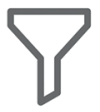

5 Step: analysis

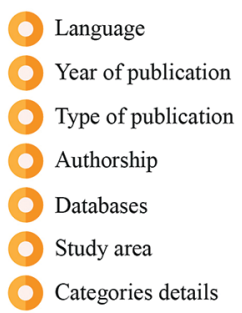

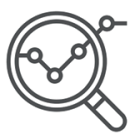

Figure 1. Multiple-step survey and analysis framework based on inclusion and exclusion criteria used to filter publications on gender and fisheries.

Table 1. Categories and respective criteria used to classify the publications selected by the review.

\begin{tabular}{|c|c|}
\hline Category & Criteria \\
\hline Demographic & Presents sociodemographic data to distinguish gender in fisheries. \\
\hline Participation & Focuses on women and their role in fisheries. \\
\hline Knowledge & Explores the women's knowledge of fisheries, marine resources, and processes. \\
\hline Livelihoods & Focuses on fisherwomen but not solely on fishing, addressing lifestyle, violence, maternity, and health issues. \\
\hline Activism & $\begin{array}{l}\text { Discusses women's participation in social movements, unions, commissions, social projects, and their } \\
\text { involvement in fighting for women's rights. }\end{array}$ \\
\hline Conservation & Discusses how women contribute to ocean conservation. \\
\hline Technology & Describes techniques and instruments used by women to fish. \\
\hline
\end{tabular}

\section{RESULTS}

\section{BibLIOMETRIC RESULTS}

The first step search resulted in 662 entries. However, since the databases selected apply different search filters (i.e., Repomar selects publications based on searches in the entire document, while the others consider only the title, abstract, and keywords), many results were not related to this subject research and were promptly excluded. Thus, our multiple-step survey and analysis resulted in a final dataset of 19 studies (Supplementary Material). All databases assessed presented results: Repomar ( $\mathrm{n}=7)$, Catálogo de Teses \& Dissertações CAPES ( $n=6)$, Web of Science $(n=4)$, and Scielo $(n=3)$. The most recent studies were from 2018 $(n=2)$; the oldest was from $2007(n=1)$. The majority of the leading authors were women $(89 \%, n=17)$ and the study areas were from Northeast $(n=11)$, South $(n=5)$, and Southeast Brazil $(n=3)$ (Figure 2).

Nearly $58 \%$ of the studies were theses and dissertations $(n=12)$, all in Portuguese. The institutions where these studies were carried out were higher in the northeast $(n=6)$, followed by South $(n=4)$ and Southeast Brazil $(n=2)$. The studies were from multiple academic 
fields, including environmental (Ecology and Natural Resources; Environment and Development; Local development); social dimensions (Education; Culture, Inequalities, and Development; Gender Studies; Social Anthropology and Participation), and management (Geography; Coastal Zone Integrated Management).

The research papers $(n=7)$ were both in English $(n=4)$ and Portuguese $(n=3)$, in journals of diversified scopes. A few of them related to ocean science (Marine Policy, $\mathrm{n}=1$; Ocean \& Coastal Management, $\mathrm{n}=1$ ), but there were also studies from journals on human sciences (Boletim do Museu Paraense Emílio Goeldi, $n=1$ ); interdisciplinary research (Ambiente e Sociedade, $n=1$; Revista Tecnologia e Sociedade, $n=1$; Anais da Academia Brasileira de Ciências, $n=1$ ) and law and public policies (Revista Gênero e Direito, $n=1$ ). The leading authors were from academic institutions based in the Northeast $(n=3)$, Southeast $(n=2)$, and South Brazil $(n=1)$, and the United States of America $(n=1)$.

\section{Language}

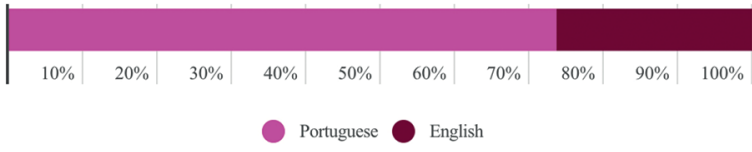

2 Year and type of publication

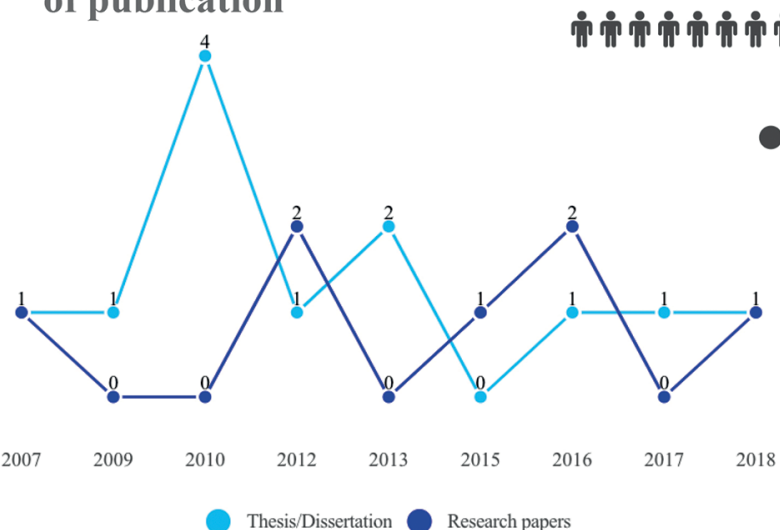

3 Authorship

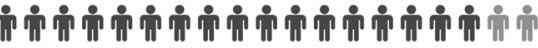

2 Database

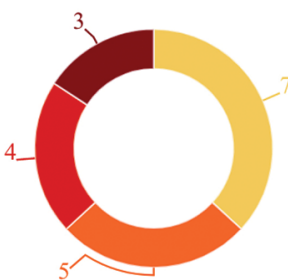

Repomar

Catálogo de Teses \& Dissertações CAPES

Web of Science
3 Study Area

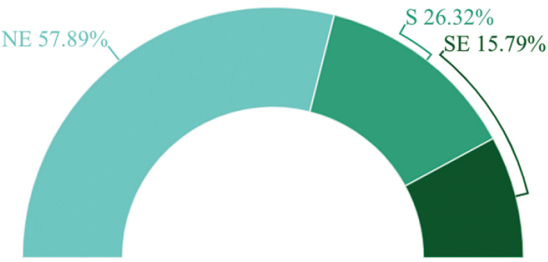

NE

Women Men

.




\section{BRAZILIAN GENDER-ORIENTED STUDIES IN FISHERIES}

All studies (numbered in the Supplementary material) discussed at least three main categories (livelihood, participation, and a third), with a 4.5 mean number of categories for the whole set. Two studies discussed all 7 categories, and most studies $(n=6)$ addressed 4 categories (Figure 3 ).

The categories (Livelihoods; Participation; Activism; Knowledge; Technology, Demographic, and Conservation) and the main issues covered by the publications are described below.

\section{Livelihoods and Participation}

All studies analyzed the Livelihoods and Participation $(n=19)$ of women in fisheries. Studies described the specific activities performed by women who, besides resource extraction, are usually responsible for post-capture processing, craftwork, fishmongering, and maintenance of fishing gear. Although studies show that women are involved in all phases of fishing processes, some registered a strong gender-biased work division which tends to understand women as fragile and weak beings whose work is limited to land or shallow-water activities, including the gear-intensive demanding crustacean and mollusk gathering $(4 ; 6 ; 9 ; 10 ; 11 ; 13 ; 16 ; 18 ; 19)$. There is a high level of invisibility and a lack of recognition of women's work in fishing $(4 ; 17)$.
Gender bias is also strong in using "marisqueiras" (i.e., women who work with shellfish resources). In some cases $(2 ; 3 ; 8)$, this term denotes a distinct cultural identity of women who dedicate themselves to gathering crustaceans and mollusks in coastal areas (e.g., opposing fisherwomen who engage in other fishing activities such as shrimp trawling or gillnet fishing). In others $(13 ; 16 ; 18)$, it is the expression of gender biases, reinforcing the hierarchy of fisherMEN and the greater importance of their work over the work performed by women. Most results describe women doing a double workday, fishing, household chores, and child care. Compared to the livelihood of fishman, some studies pointed out that women have a higher educational level and assume more diverse tasks (11). When a woman does work related to fishing, she contributes to the family income (11).

\section{Activism}

Women's interaction with social movements, unions, commissions, social projects, and women's rights advocacy was discussed in $68.4 \%$ of the studies $(n=13)$. Most studies stated that men dominate the social participation arena (e.g., fishing colonies, unions, and associations meetings) $(n=11)$. However, with time, women have been creating spaces and

\section{Categories in studies}
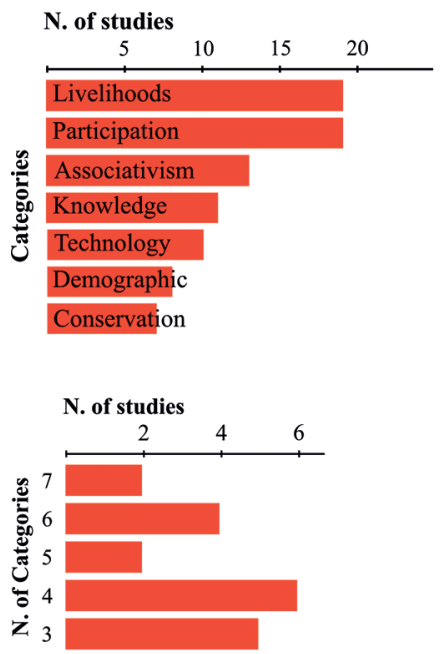

\section{Categories combinations}

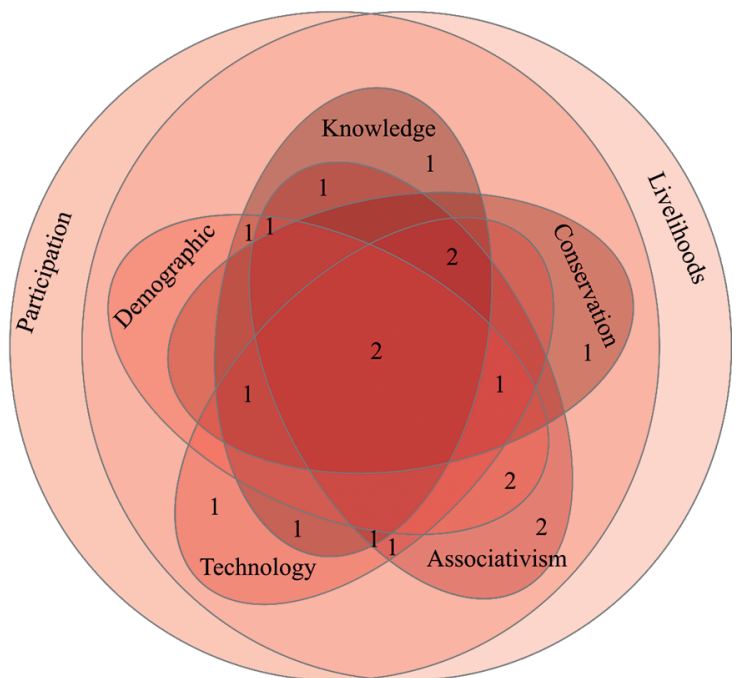

Figure 3. Categories discussed in each study were selected in the literature review. We present the number of studies that addressed each category, the number of studies that addressed multiple categories, and the combination of categories addressed in the studies. 
building a network to support their participation, initially as observers and gradually occupying roles of advisers and even administrative leading roles within fisheries associations, as secretaries and presidents (3). The relationship of women with activism faces several challenges $(2 ; 10)$, including labor division and the need to reconcile household work and family care. In many cases, women lack support from husbands to participate in such arenas or find the complexities and specificities of discussions uninteresting. Women's participation was generally more consolidated in cases related to ensuring social rights $(15 ; 18)$.

\section{KNOWLEDGE}

The knowledge of women in fisheries was considered in 11 studies $(3 ; 6 ; 9 ; 8 ; 12 ; 13 ; 15 ; 14 ; 16 ; 17 ; 18)$ that discussed the role of women in communicating this knowledge to younger generations and the empirical knowledge women have on fisheries (e.g., extraction and trading), fishing gear, fishing resources, and marine ecological processes. Since childhood, such knowledge has been present in women's lives $(3 ; 6 ; 8 ; 12 ; 13 ; 15 ; 17 ; 18)$. Children's first contact with fisheries usually happens by observing and later assisting their mothers in fishing activities. Teaching their children about fisheries is a means to guarantee a future occupation, a profession, a means to survive and support their prospective families. Women undertake this task as a responsibility.

One study (8) also discussed local and traditional sea tenure regimes. In some cases, fishing grounds for men and women are pretty distinct. While men fish in coastal or marine waters, women fish in coastal ecosystems such as mangroves (as is the case of "marisqueiras") and have a unique relationship with such ecosystems and also a different understanding of and perspective on their environment (8). Given their restricted mobility, pressures such as mariculture development or coastal pollution have driven women away from their traditional territories towards maledominated areas, thus changing their practices.

\section{TECHNOLOGY}

Data regarding fishing Technology appeared in 10 studies $(3 ; 4 ; 6 ; 8 ; 9 ; 11 ; 12 ; 14 ; 15 ; 17)$. All studies described fishing gear, and some described how women have created and improved fishing equipment to contribute to selective management of target species $(8 ; 17)$. Studies also described the infrastructure available for the fish processing phase $(3 ; 4 ; 6 ; 7 ; 8 ; 11$; $12 ; 15)$ and how human resources $(8 ; 12)$ are involved in this work. Adaptations developed by women for fishing $(3 ; 4 ; 7 ; 8 ; 12 ; 14 ; 15 ; 17)$ were also mentioned in studies in this category.

\section{DeMOgRaPhIC}

Demographic data to support discussions about gender in fisheries were used in 8 studies $(3 ; 5 ; 6 ; 9$; $10 ; 11 ; 13 ; 15)$. They reported socioeconomic data such as age, education, number of children, and marital status. Some also presented the household condition $(6 ; 15)$, access to fishing insurance (15), and fisherwomen income $(9 ; 15)$. These data, disaggregated by sex, helped to establish the fisherwomen profile for each study.

\section{Conservation}

The role of women in the Conservation of fishing resources appeared in 6 studies $(1 ; 3 ; 6 ; 8 ; 11 ; 15)$. They pointed out three aspects that highlight this relationship. First, as women usually work every day in the same spot, such as mangroves and estuaries, they build a strong knowledge of the ecosystem dynamics and natural resources (6). They can act as monitors for any environmental change (8). Second, women use more traditional fishing methods and techniques that empirically contribute to the growth of the target species, such as selective capture, by avoiding catching young individuals $(1 ; 3 ; 15)$. Third, women often present soft skills necessary for environmental conservation and sustainable development, such as adaptive learning, flexibility, and diversification to deal with changes and uncertainties (11).

\section{Main CHALLenges REPORTED IN THE STUDies}

Fisheries is a challenging activity for men and women, which was discussed by 16 studies $(1 ; 2 ; 3$; $4 ; 5 ; 7 ; 8 ; 10 ; 11 ; 12 ; 13 ; 14 ; 16 ; 17 ; 18 ; 19)$. Challenges faced by men and women are i) dependence on a middleman (8); ii) difficulties in resources' management such as dealing with increasingly irregular and scarce capture $(3 ; 12 ; 19)$; dealing with environmental degradation, often caused by external activities such as agriculture, industry, and shrimp farming $(3 ; 12$; 13); iii) lack of social mobilization and organization of 
the fishing communities, evidenced by a lack of trust in governmental bodies and feeling of being powerless in the face of big companies that damage their activities (3); iv) lack of public health care policies orientated towards the fishing communities (5), and v) high risk of working accidents (12).

Fisherwomen face different challenges than men do. Women have more difficulty in obtaining a legal register of their fishing profession, making it harder to access bank credit, legal rights, and benefits conceded to fishermen $(3 ; 5 ; 8 ; 11 ; 12 ; 16 ; 18)$. This reality also links to a lack of acknowledgment of a woman as a fish worker, both by the government and by men of the community, e.g., father, brothers, husband $(3 ; 5 ; 11 ; 12 ; 13 ; 14 ; 16 ; 18)$, and promotes unequal access to resources, property rights, social representation, and decision-making power within the community (11). Additionally, this lack of acknowledgment results in market price devaluation of products sold by fisherwomen $(3 ; 18)$ and social stigma, e.g., many women are ashamed of having this as a livelihood (4; 5). Furthermore, women have to deal with the double work journey, i.e., work duties both outside and inside the home, much more than men $(3 ; 11 ; 16 ; 18)$. Women also face poor working conditions, such as high exposure to sunlight without proper protection, exposure to unhealthy water quality, which can cause diseases, and lack of suitable equipment for working $(3 ; 5 ; 12 ; 13 ; 14$; $17 ; 18)$. Finally, women face cultural barriers (e.g., having a woman in the fishing boat is considered bad luck) (16) and domestic violence $(5 ; 4)$.

\section{DISCUSSION}

There are nearly two million artisanal fish workers in Brazil, and 45\% are women (FAO, 2019). Among the ones that are responsible for post-capture activities or supporting fishing in general, women are $90 \%$ of the workforce (FAO, 2019). They are involved in shellfish gathering, weaving of fishing nets, capture, food production and processing, handicrafts, industries and salt marsh labor, and the maintenance of domestic activities. The studies selected for this review show that women are present in fisheries; the issues they face must be considered when planning an ocean sustainability agenda.

The following section aims to draw insights from the panorama of gender and fisheries research field to reveal how this debate can be highlighted during the Ocean Decade and SDGs 5 and 14. We extracted the primary information from the selected thematic categories (Livelihoods; Participation; Activism; Knowledge; Technology, Demographics, and Conservation) to draw insights into understanding the barriers women face in the fisheries sector and how research regarding these subjects is addressing such challenges.

\section{Gender APPROACHES FOR THE OCEAN DeCADE: INSIGHTS for a Sustainable Development agenda}

Inclusive and interdisciplinary science is a longterm goal for the future society wants and the ocean it needs (Mooney et al., 2013). The Ocean Decade emerges as an opportunity to produce usable knowledge (i.e., salient and legitimate) with marine science that could support the decision-making process to implement the SDGs agenda, including gender equality and the empowerment of women (SDG 5).

The progress in implementing the 2030 Agenda has been unacceptably slow globally, with stagnation and even regression in some contexts (Odera and Mulusa, 2020), especially to reach gender balance in vulnerable populations (De La Torres-Castro, 2019). Gender equality is a cross-cutting development issue, so it requires a multi-dimensional implementation process to become realistic and inclusive of women and girls as equal partners for sustainable development (Odera and Mulusa, 2020). The SDG 5 also has targets related to gender-based violence, harmful practices, unpaid care work, lack of voice, sexual and reproductive health and rights, economic resources, technology, and legislative change (Fukudar-Parr, 2016). Many of those topics appeared in the studies analyzed in this bibliographic review as challenges faced by fisherwomen, such as discrimination, double work journey, difficulties in receiving social benefits, and lower incomes from fishing.

Although relevant, such topics are very womenfocused and, if not carefully considered, they risk leaving complex social discussions out of the debate. Gender issues transcend the focus on women; they are socially constructed and reflect societal values and norms on how people behave and relate (Scott, 1986). To address gender inequalities, both men and women must be involved in deeper discussions and reframing social constructs that enable power imbalances. For fisheries, gender discussions tend to focus on the sexual division of labor (the studies analyzed 
in this review and Lawless et al., 2021), a limited range to face gendered relationships. When gender is shrunk to a limited meaning, the possibilities to promote societal changes are also curtailed (Lombardo et al., 2010; Lawless et al., 2021).

Much work remains to systematically integrate gender lenses into relevant domains of science and management (Tannenbaum et al., 2019), such as fisheries science. This step is crucial to defining research priorities, designing inclusive public policies and guidelines, and interpreting the data and information already available. During the Ocean Decade and the subsequent years of efforts towards implementing the $2030 \mathrm{Agenda}$, there is a need for coordinated interest and responsibility in considering gender issues in marine sciences. The public sector, researchers, funding agencies, peer-reviewed journals, NGOs, and universities can foster science to be more applied to the world's real problems. Taking inclusiveness into account could remove the marine science field's historical barriers (Worm et al., 2021).

The SDG Agenda is due in 2030, but while states endeavor to implement it, civil society can discuss and seek a transformation of those goals (Sachs et al., 2019), where life below water and gender equality are connected and interdependent. If in the past, the Millenium Development Goals were considered insufficient to address environmental objectives (Sachs, 2012), there is also a widespread understanding that more connection among the SDGs is required to meet worldwide challenges (Le Blanc, 2015; Sachs et al., 2019). Complementary actions carried out by stakeholders should pursue deeper transformations respecting the strong interdependencies across the 17 SDGs (Sachs et al., 2019). An articulated approach would help guide the design of appropriate governance tools to guarantee that the SDG agenda leaves neither women nor girls involved in fisheries behind.

With this in mind, we provided five recommendations for the Ocean Decade that could help to foster a transformation that engages with gender and supports women in fisheries: make the hidden workforce visible; embrace interdisciplinarity; set gender-focused research priorities; fill the data gap and promote public policies that support gender-equitable fisheries.

\section{MAKE THE "HIDDEN WORKFORCE" VISIBLE}

Discrimination against women and the difficulties in maintaining power and occupying spaces that women did not previously occupy are significant challenges. Gender equality is fundamental to any development, and this goes through recognizing the vital role of women in fisheries. Interestingly, we searched for studies on any fishing regime, but only studies discussing small-scale artisanal fisheries were identified. However, women are working in different post-harvest activities, providing labor in commercial and artisanal fisheries (Choo et al. 2008; FAO, 2020). The identification of studies of artisanal fisheries alone indicates that the fisheries sector needs more studies in Brazil.

When referring to fisherwomen, the literature recurrently concludes that fishing was, and still is, a space reserved for men and for what is historically designated as masculine: strength, courage, determination (Silva et al., 2020). Women are not recognized formally as fish workers, instead their work is considered 'assisting' their husbands/relatives in pre- and post-harvest activities. Women also have little or no decision-making power as they usually don't own boats and are yet responsible for household chores and care for children (Martinez and Hellebrandt, 2019; Silva et al., 2020).

The reality, though, is different. Women have been in the ocean in various capacities (Kleiber et al., 2015). Moreover, when performing their role, they do it differently from men: women tend to fish in different areas than men and target other species. Disregarding the role of women in fishery management implies leaving out of management discussions many relevant species and environments that support extensive marine and terrestrial food webs, such as mangroves (Rocha et al., 2012; Kleiber et al., 2015). Their proximity and daily observation of such ecosystems unveil information that fisherfolks from other areas are unaware of (Santos, 2015).

\section{EMBRACE INTERDISCIPLINARITY}

Gender studies are part of a broader shift towards academic interdisciplinarity (Woodward and Woodward, 2015). They are dispersed and heterogeneous and transcend a single discipline. For Bennet 
(2005), although gender roles are crucial for fishing communities, they are primarily featured in anthropological studies and are often ignored in economic or social research (Bennett, 2005). In a review of gender studies in Switzerland, Söderlund and Madison (2015) showed that few natural scientists engage in gender studies. In a complex social-ecological context, disciplinary studies are insufficient. Interdisciplinarity offers theoretical and methodological advantages in understanding multiple constituted social and natural worlds and addressing pressing global problems, such as food security, climate change, and health. A connection among the fields is needed.

For a long time, fisheries studies have overlooked gender issues (Smith and Basurto, 2019). The limited definition of fisheries (focusing on male-dominated at-sea activities) and the lack of disaggregated data perpetuate gender-blind research agendas and fisheries policies. To develop gender and fisheries research, marine scientists could work closely with other researchers whose expertise is in gender, human rights, and development fields (Choo et al., 2008). Together, natural and social science may enrich the subject and allow a more comprehensive and diverse understanding of the social representations of women's role in fisheries.

A redesign of marine sciences to include social sciences is desirable (Oliveira et al., 2021). Society must be the primary beneficiary of scientific production that fosters social-environmental transformation. For this, the Humanities are essential disciplines to assess the social and human dimensions of natural sciences related to studying the connection between gender and the ocean.

Through the years, marine sciences are evolving as a field and becoming increasingly more inter- and transdisciplinary. A new branch of marine studies has gained the spotlight in Brazil, known as human, social or social-environmental oceanography (Moura, 2017; 2019). This emerging field discusses, as an example, ethnography, local and traditional knowledge, coastal management, anthropogenic impacts, and environmental education. Fisheries science is often merged within these subjects, and there is a gap for gender-oriented research along with the broader approach of marine sciences.

\section{SeT GENDER-FOCUSED RESEARCH PRIORITIES}

Although increasing in Brazil and worldwide (Maneschy et al. 2012; Söderlung and Madison, 2015; Souza et al., 2019), gender studies are still not prioritized for research centers and funding agencies. Women's labor contributions are critical to maintaining artisanal fisheries livelihoods; however, the number of fisheries publications on the theme of gender remain limited. To develop this research area, the Ocean Decade should explicitly include gender as a research priority.

Brazil's large marine territory, also called the "Blue Amazon," has the immense potential to improve the debate for SDG 14, fisheries, and interdependencies. The focus on a Blue Economy through the Ocean Decade can lead marine development towards a more just, sustainable, and equitable future and requires a priority investment in ocean science and interdisciplinarity (Barros-Platiau et al., 2021). However, the systematic reduction of the budget for science in Brazil (Tollefson, 2019; Oliveira et al., 2020) has affected ocean development. Despite the large coastal and marine area, investments in ocean science are lower than $0.5 \%$ of investments in research and development (IOC-UNESCO, 2020). The low budget highlights the inequalities regarding infrastructure and financial resources already faced by academic institutions where studies of gender in fisheries could take off.

The majority of gender-fisheries studies in Brazil are from researchers in institutions located in the Northeast region, studying their local area. Souza et al. (2019) reported the same trend, which diverges from the national pattern of scientific production, usually higher in Brazil's Southeast and South regions (Sidone et al., 2016). The higher number of studies from Northeast Brazil is not coincidental. Most artisanal fishery production is from this coastal region, representing $48 \%$ of the total catches from Brazil (Vidal and Gonçalves, 2008). The Northeast coast is the area with high mangroves coverage (MMA, 2018), which enables activities that are performed mainly by women (i.e., "mariscagem").

Despite this prominent position in gender studies, investments in research development in the northeast are not a federal priority. State investment in research and development is scarce compared to 
the Southeast ( $R \$ 1$ and $R \$ 12$ million, respectively). Additionally, when investments exist, gender studies are overlooked since most projects focus on natural science. As an illustrative example, among the projects selected by two calls for projects regarding a major oil spill that reached Northeast Brazil (15 from the Brazilian Coordination for the Improvement of Higher Education Personnel - CAPES Process 23038.017978/2019-05; and 11 from the Brazilian National Council for Scientific and Technological Development - (NPq) and impacted artisanal fisherfolk and coastal communities (Gonçalves et al., 2020), none of them focus on gender and research centers from the northeast lead only half of them.

Besides fostering research development, it is also crucial to make Brazilian studies known worldwide. The two most cited publications from our selection (Di Ciommo and Schiavetti, 2012 and Santos, 2015) were the ones published in Marine Policy and Ocean \& Coastal Management (i.e., near 45 citations at Google Scholar), which represents a high citation rate for articles on the theme (Söderlund and Madison, 2015). However, our results demonstrated that most gender-fisheries publications are Portuguese (73.7\%) and consist of grey literature (63.2\%). Such numbers indicate that the scientific literature from Brazil is not reaching a broader audience to disseminate the realities from the Global South. Indeed, there is an indication that articles about women in fisheries or gender and fisheries face more significant barriers reaching high-impact journals (Frangoudes and Gerrard, 2018, p. 118). Additionally, Brazilian authors face additional challenges in publishing their work in high-impact journals and foreign language journals (Fradkin, 2017; Souza et al., 2019). Thus, investing in capacity building and undergraduate and postgraduate education is crucial.

Authorship of most of the literature from our review belongs to women (89.5\%). According to Souza et al. (2019), only $17 \%$ of publications about gender and fisheries were written by men, leaving women to think, reflect and highlight how relevant and obscured the subject still is. When scientific production is gendered, the topic is gaining attention only from those who feel the impact of the problem. It is a knowledge disconnect where the entire community has not addressed the issue (Martinez and Hellebrandt, 2019).

\section{FILL THE DATA GAP}

Small-scale fisheries serve as an economic and social engine, providing sustenance and food security, employment, and other multiplier effects to local economies while underpinning the livelihoods of communities worldwide (FAO, 2020). Gender studies on fisheries and aquaculture may act as an effort to expand fishing science beyond stock analysis and the male -dominated fishing industry (Williams, 2008).

The underestimated importance of women's roles in fisheries suppresses discussions on workload and informality once women continue leading activities considered secondary in fishing and are simultaneously considered responsible almost exclusively for reproductive work (Silva et al., 2020). In general, fisherwomen are given the most unstable, underpaid, or unpaid positions, which require lesser professional qualifications (e.g., secondary sector) (Maneschy and Álvares, 2005). One reason for this negligence toward women is the lack of data and studies on gender in fishing science.

The Food and Agriculture Organization of the United Nations (FAO) recognized the information gap and intend to advance data systematization on fisheries and gender in partnership with the Organization for Economic Co-operation and Development (OECD). They aim to ensure a more accurate and comprehensive assessment of the importance of women's contributions to production, trade, food security, and livelihoods in fisheries and aquaculture (FAO, 2020).

This information may even contribute to better integration of SDG 5 and SDG 14. Sustainability in fisheries and aquaculture can catalyze equality in society as a whole, promoting gender equality, ensuring labor rights, and adopting social protection schemes. During the Ocean Decade, it is critical to develop monitoring and assessment programs that provide open access to data, information, and technologies for the predictability, the sustainable harvesting of the ocean, and the correct development and design of gender-sensitive fisheries and aquaculture policies. 
Promote public policies that support genderEQUITABLE FISHERIES

One important rule in Brazil regarding fisherwomen is Statute 13,902 from 2019. It clarifies the development of a policy for the activities performed by "marisqueiras." By this regulation, marisqueiras have acquired the right to access public programs such as the PRONAF (Portuguese acronym for National Program of Strengthening Family Agriculture). The Statute contributes to define the fisherwomen category and promote their visibility and the motivation to create cooperatives and engage in collective actions. However, comprehensive and broader public policies must be fostered and implemented to improve gender equality, such as the National Policy for the Sustainable Development of Aquaculture and Fisheries (Law 11, 959 of 2009), which needs revising. A strategy that the Brazilian fisherwomen have claimed is establishing a special secretary within the national fishery department (SEAP, 2006; Azevedo, 2012).

As long as there are no public policies that effectively promote gender equality in fishing, recognizing the role of women in care and domestic work, and ensuring their participation in decision-making with access to social, economic, and natural resources, the whole issue will not be addressed (Silva et al., 2019). Assessment, review, and synthesis of information on fisheries worldwide are fundamental to advancing knowledge and adapting it to promote better public policies. Still, today, fisherwomen need to claim their rights and justify their work and livelihood to have access to social policies (Gerber, 2013; Gustavsson, 2020). According to the FAO (2020), one out of two seafood workers in the primary and secondary seafood sectors is a woman. It thus makes sense to recognize that achieving gender equality requires concerted efforts and that gender mainstreaming should be an integral part of all small-scale fisheries management strategies.

Ocean science and policies are evolving to integrate the needs of society and encourage informed decisions and knowledge acquisition towards shared rights and resources. There is still much to do to ensure environmental justice for residents of coastal communities such as fisherwomen, vulnerable to current and future changes in the ocean (Gustavsson et al., 2021). The more awareness and empowerment of women are built up within fisheries research, management and policy-making, the closer we get to achieving shared global goals and commitments for sustainable development.

\section{FINAL CONSIDERATIONS}

The studies considered for this review describe the activities performed by women, their socioeconomic condition, their distinct cultural identities and report how they organize themselves for claiming their rights. The publications also expressed the gender biases in the hierarchy of fishing work. They highlighted women's empirical knowledge by transforming their land and households into fishing territories, developing techniques, gear, and adaptations to better manage natural resources and monitor environmental change. All categories (Livelihoods; Participation; Activism; Knowledge; Technology, Demographic, and Conservation) used to classify the publications disclose a diversity of the fisherwomen roles in fishing in Brazil and unveil the complexity in analyzing data disaggregated by sex. On the one hand they are invisible in the system, but on the other hand, the literature indicates they have been present in marine affairs and fishing activities in different ways. This valuable information pack is not yet organized, accessible, or employed in developing gender-led monitoring programs and public policies for fisheries.

The analyzed publications show that women are present in fisheries and are fundamental subjects to maintaining the activity and continuity of this livelihood. The widespread sociopolitical invisibility of these women contradicts the reality of the fish workers. All this evidence highlights public policy flaws that risk the sustainability of artisanal fisheries, at the same time offering science-based evidence that could (and should) support new rules closer to the local realities. From a human rights perspective, the interdisciplinary proposal of the SDGs and the Ocean Decade can help people recognize the diversity of work and life relationships with marine socio-ecological systems.

Understanding barriers women face in the fisheries sector is challenging, especially when we note the sparsity of research studies. Although the current body of research concerning gender and fisheries in Brazil started in the 1970s, many questions still need to be addressed, especially as policies progress and 
ecosystems continue to change under the pressures of growing populations and climate change. More and more, women are expanding their participation in fisheries in Brazil and worldwide, demanding to be heard and seen as subjects of the fisheries sector. But scientific production has lagged to document and debate the connection of both topics. As future studies evolve, it seems relevant to address the challenges of women in the fisheries sector through public policies and the assessment of the fisherwomen populations and groups.

This review and analysis intends to fill some gaps in women's aid to fisheries sustainability and contribute with some recommendations to define gender-led goals for sustainable development commitments, such as the UN Decade of Ocean Science for Sustainable Development and the 2030 Agenda. We argue for a transformative approach in the ocean sciences that can address the social-nature interface that needs to see, consider, and value women's role as leading actors and gender as key focal area of fisheries research.

\section{ACKNOWLEDGMENTS}

We thank the São Paulo Research Foundation (FAPESP) for the support for developing this research (LYX: 2017/21797-5; LRG: 2018 / 00462- 8).

\section{AUTHOR CONTRIBUTIONS}

M.M.A.: Conceptualization; Data curation; Formal analysis; Methodology; Visualization; Writing original draft; Writing - review \& editing.

L.Y.X.: Conceptualization; Data curation; Formal analysis; Methodology; Visualization; Writing original draft; Writing - review \& editing.

N.M.G.: Conceptualization; Data curation; Formal analysis; Methodology; Visualization; Writing original draft; Writing - review \& editing.

C.C.O., D.A.A., G.C.B., L.H., M.C.G., S.T.S., T.C.F.: Writing - review \& editing.

L.R.G.: Conceptualization; Data curation; Formal analysis; Methodology; Visualization; Writing - original draft; Writing - review \& editing; Supervision.

\section{REFERENCES}

AGARWAL, B. 2009. Gender and forest conservation: the impact of women's participation in community forest governance. Ecological Economics, 68(11), 2785-2799.
ALENCAR, E. 1991. Pescadeiras, companheiras e perigosas: a pesca feminina na Ilha de Lençóis. MSc. Brasília: UNB (Universidade de Brasília).

AZEVEDO, N. T. 2012. Política nacional para o setor pesqueiro no Brasil (2003-2011). DSc. Paraná: UFPR (Universidade Federal do Paraná), Programa de Pós-graduação em meio Ambiente e Desenvolvimento (PPGMADE).

BARRETO, G. C., DI DOMENICO, M. \& MEDEIROS, R. P. 2020. Human dimensions of marine protected areas and small-scale fisheries management: a review of the interpretations. $\mathrm{Ma}$ rine Policy, 119, 104040.

BARROS-PLATIAU, A. F., GONÇALVES, L. \& OLIVEIRA, C. C. 2021. A década da ciência oceânica como oportunidade de justiça azul no sul global. Conjuntura Austral, 12(59), 11-20.

BENNETT, E. 2005. Gender, fisheries and development. Marine Policy, 29(5), 451-459.

BRASIL. Ministério do Meio Ambiente. Instituto Chico Mendes de Conservação da Biodiversidade. 2018. Atlas dos Manguezais do Brasil/Instituto Chico Mendes de Conservação da Biodiversidade [online]. Brasília: Instituto Chico Mendes de Conservação da Biodiversidade. Available at: https://www.icmbio.gov.br/portal/images/stories/manguezais/atlas_dos_manguezais_do_ brasil.pdf [Accessed: 15 November 2021].

CHOO, P. S., NOWAK, B. S., KUSAKABE, K. \& WILLIAMS, M. J. 2008. Guest editorial: gender and fisheries. Development, 51, 176-179.

CHUENPAGDEE, R., LIGUORI, L., PALOMARES, M. L. D. \& PAULY, D. 2006. Bottom-up, global estimates of small-scale marine fisheries catches. Fisheries Centre Research Reports, 14(8), 105.

CLAUDET, J., BOPP, L., CHUNG, W. W. L., DEVILLERS, R., ESCOBAR-BRIONES, E., HAUGAN, P., HEYMANS, J. J., MASSON-DELMOTTE, V., MATZ-LÜCK, N., MILOSLAVICH, P., MULLINEAUX, L., VISBECK, M., WATSON, R., ZIVIAN, A. M., ANSORGE, I., ARAUJO, M., ARICÒ, S, BAILLY, D. \& GAILL, F. 2020. A roadmap for using the UN decade of ocean science for sustainable development in support of science, policy, and action. One Earth, 2(1), 34-42.

DE LA TORRE-CASTRO, M. 2019. Inclusive management through gender consideration in small-scale fisheries: the why and the how. Frontiers in Marine Science, 6, 156.

DI CIOMMO, R. C. \& SCHIAVETTI, A. 2012. Women participation in the management of a Marine Protected Area in Brazil. Ocean \& Coastal Management, 62, 15-23.

FAO (Food and Agriculture Organization of the United Nations). 2015. Voluntary guidelines for securing sustainable small-scale fisheries in the context of food security and poverty eradication [online]. $2^{\text {nd }}$ ed, Rome: FAO. Available at: http://www.fao.org/3/ i4356en/i4356en.pdf [Accessed: 15 November 2021].

FAO (Food and Agriculture Organization of the United Nations). 2019. Fishery and aquaculture country profiles: the Federative Republic of Brazil [online]. Rome: FAO. Available at: http://www. fao.org/fishery/facp/bra/en [Accessed: 15 November 2021].

FAO (Food and Agriculture Organization of the United Nations). 2020. The state of world fisheries and aquaculture 2020. In: FAO, (ed.). Sustainability in action [online]. Rome: FAO. Available at: http://www.fao.org/documents/card/en/c/ ca9229en [Accessed: 15 November 2021].

FRADKIN, C. 2017. Scientific publication for nonnative English speakers: a retrospective of a workshop in Brazil. Science Communication, 39(3), 395-403.

FRANGOUDES, K. \& GERRARD, S. 2018. (En)gendering change in small-scale fisheries and fishing communities in a globalised world. Maritime Studies, 17, 117-124. 
FREITAS, C. T., ESPÍRITO-SANTO, H. M. V., CAMPOS-SILVA, J. V., PERES, C. A. \& LOPES, P. F. M. 2020. Resource co-management as a step towards gender equity in fisheries. Ecological Economics, 176, 106709.

FUKUDA-PARR, S. 2016. From the millennium development goals to the sustainable development goals: shifts in purpose, concept, and politics of global goal setting for development. Gender and Development, 24(1), 43-52.

GALVÃO, M. C., MEDEIROS, R. P. \& NETO, F. Q. V. 2020. Estratégias adaptativas dos modos de vida e os papéis das muIheres em um sistema socioecológico pesqueiro artesanal no sul do Brasil. In: SEIXAS, C. S., VIEIRA, P. F. \& MEDEIROS, R. P. (eds.). Governança, conservação e desenvolvimento em territórios marinhos-costeiros no Brasil. São Carlos: RiMa, pp. 223-242.

GERBER, R. M. 2013. Mulheres e o mar: uma etnografia sobre pescadoras embarcadas na pesca artesanal no Litoral de Santa Catarina, Brasil. MSc. Florianópolis: UFSC (Universidade Federal de Santa Catarina), Centro de Filosofia e Ciências Humanas, Programa de Pós-Graduação em Antropologia Social.

GONÇALVES, L. R., WEBSTER, D. G., YOUNG, O., POLETTE, M. \& TURRA, A. 2020. The Brazilian Blue Amazon under threat: why has the oil spill continued for so long? Ambiente \& Sociedade, 23(1), 1-9.

GUSTAVSSON, M. 2020. Women's changing productive practices, gender relations and identities in fishing through a critical feminisation perspective. Journal of Rural Studies, 78, 36-46.

GUSTAVSSON, M., FRANGOUDES, K., LINDSTRÖM, L., ÁVAREZ, M. C. \& CASTRO, M. T. 2021. Gender and blue justice in small-scale fisheries governance. Marine Policy, 133, 104743.

GUSTAVSSON, M. \& RILEY, M. 2018. Women, capitals and fishing lives: exploring gendered dynamics in the Llŷn Peninsula small-scale fishery (Wales, UK). Maritime Studies, 17, 223231.

HANSFORD, F. 2016. A review of evidence across the minority and majority worlds. Background paper prepared for Progress of the World's Women 2019-2020. New York: UN Women.

HARPER, S., ZELLER, D., HAUZER, M., PAULY, D. \& SUMAILA. R. U. 2013. Women and fisheries: contribution to food security and local economies. Marine Policy, 39, 56-63.

IOC-UNESCO (Intergovernmental Oceanographic Commission - United Nations Educational, Scientific and Cultural Organization). 2020. Global Ocean Science Report 2020-Charting capacity for ocean sustainability, executive summary [online]. Paris: UNESCO Publishing. Available at: https://en.unesco.org/gosr [Accessed: 15 November 2021].

KLEIBER, D. L., FRANGOUDES, K., SNYDER, H., CHOUDHURY, A., COLE, S. M., SOEJIMA, K., PITA, C., LAVOIE, A., MCDOUGALL, C. L., PETRCIS, H. \& PORTERS, M. 2017. Promoting gender equity and equality through the small-scale fisheries guidelines: experiences from multiple case studies. In: JENTOFT, S., CHUENPAGDEE, R., BARRAGÁN-PALADINES, M. \& FRANZ, N. (eds.). The small-scale fisheries guidelines: global implementation. Cham: Springer, v. 2, pp. 737-759.

KLEIBER, D. L., HARRIS, L. M. \& VINCENT, A. C. J. 2015. Gender and small-scale fisheries: a case for counting women and beyond. Fish and Fisheries, 16(4), 547-562.
LAWLESS, S., COHEN, P. J., MANGUBHAI, S., KLEIBER, D. \& MORRISON, T. H. 2021. Gender equality is diluted in commitments made to small-scale fisheries. World Development, 140, 105348.

LE BLANC, D. 2015. Towards integration at last? The sustainable development goals as a network of targets. Sustainable Development Officer, 23(141), 176-187.

LE BLANC, D., FREIRE, C. \& VIERRO, M. 2017. Mapping the linkages between oceans and other sustainable development goals: a preliminary exploration. Sustainable Development Officer, 1(149), 1-34.

LOMBARDO, E., MEIER, P. \& VERLOO, M. 2010. Discursive dynamics in gender equality politics: what about "feminist taboos"?. European Journal of Women's Studies, 17(2), 105-123.

MANESCHY, M. C. \& ÁLVARES, M. L. 2005. Identities in construction and in conflict: restructuring and the social roles of women in the fishing communities Pará State, Brazil. In: NEIS, B., BINKLEY, M., GERRARD, S. \& MANESCHY, M. C. (eds.). Changing tides: gender, fisheries and globalization. Halifax: Fernwood Publishing, pp. 51-63.

MANESCHY, M. C., SIQUEIRA, D. \& ÁLVARES, M. L. M. 2012. Pescadoras: subordinação de gênero e empoderamento. Revista Estudos Feministas, 20(3), 384.

MARTINEZ, S. A. \& HELLEBRANDT, L. 2019. Mulheres na atividade pesqueira no Brasil: uma introdução [online]. Campos de Goyatacazes: EDUENF (Editora da Universidade Estadual do Norte Fluminense Darcy Ribeiro). Available at: https:// www.funbio.org.br/wp-content/uploads/2019/08/Mulheres_na_Atividade_Pesqueira_no_Brasil.pdf [Accessed: 15 November 2021].

MOONEY, H. A., DURAIAPPAH, A. \& LARIGAUDERIE, A. 2013. Evolution of natural and social science interactions in global change research programs. Proceedings of the National Academy of Sciences of the United States of America, 110(Suppl 1), S3665-S3672.

MOTTA-MAUÉS, M. A. 1999. Pesca de homem/peixe de mulher (?): repensando gênero na literatura acadêmica sobre comunidades pesqueiras no Brasil. Etnográfica, 3(2), 377-399.

MOURA G. G. M. 2017. Avanços em oceanografia humana: o socioambientalismo nas ciências do mar. Jundiaí: Paco Editorial.

MOURA, G. G. M. 2019. Construção da crítica à oceanografia clássica: contribuições a partir da oceanografia socioambiental. Ambiente \& Educação, 24(2), 13-41.

ODERA, J. A. \& MULUSA, J. 2020. SDGs, gender equality and women's empowerment: what prospects for delivery? In: KALTERNBORN, M., KRAJEWSKI, M. \& KUHN, H. (eds.). Sustainable development goals and human rights. Cham: Springer, pp. 95-118.

OLIVEIRA, C. C., FARRANHA, A. C., BARROS-PLATIAU, A. F., COUTINHO, L., FEODRIPPE, R., GRILLI, N. M., ANDRADE, M. M., GONÇALVES, L. R. \& DALPAZ, L. 2021. Brazilian examples help to propose a social-natural interface guideline for the Ocean Decade. Eco Magazine, 3, 130-133.

OLIVEIRA, E. A., MARTELLI JÚNIOR, H., SILVA, A. C. S., MARTELLI, D. R. B. \& OLIVEIRA, M. C. L. 2020. Science funding crisis in Brazil and COVID-19: Deleterious impact on scientific output. Anais da Academia Brasileira de Ciências, 92(4), e202007000. 
PLUMMER, B., CRONA, D. R., ARMITAGE, P., OLSSON, P., TENGÖ, M. \& YUDINA, O. 2012. Adaptive co-management: a systematic review and analysis. Ecology \& Society, 17(3), 11.

ROCHA, M. S. P., SANTIAGO, I. M. F. L., CORTEZ, C. S., TRINDADE, P. M. \& MOURÃO, J. S. 2012. Use of fishing resources by women in the Mamanguape River Estuary, Paraíba state, Brazil. Anais da Academia Brasileira de Ciências, 84(4), 1189-1199.

ROHE, J., SCHLÜTER, A. \& FERSE, S. C. A. 2018. A gender lens on women's harvesting activities and interactions with local marine governance in a South Pacific fishing community. Maritime Studies, 17, 155-162.

RYABININ, V., BARBIÈRE, J., HAUGAN, P., KULLENBERG, G., SMITH, N., MCLEAN, C., TROISI, A., FISCHER, A., ARICOे, S., AARUP, T., PISSIERSSENS, P., VISBECK, M., ENEVOLDSEN, H. O. \& RIGAUD, J. 2019. The UN decade of ocean science for sustainable development. Frontiers in Marine Science, 6, 470.

SACHS, J. D. 2012. From millennium development goals to sustainable development goals. The Lancet, 379(9832), 2206-2211.

SACHS, J. D., SCHMIDT-TRAUB, G., MAZZUCATO, M., MESSNER, D., NAKICENOVIC, N. \& ROCKSTRÖM, J. 2019. Six transformations to achieve the sustainable development goals. Nature Sustainability, 2, 805-814.

SANTOS, A. N. 2015. Fisheries as a way of life: gendered livelihoods, identities and perspectives of artisanal fisheries in eastern Brazil. Marine Policy, 62, 279-288.

SCOTT, J. W. 1986. Gender: a useful category of historical analysis. The American Historical Review, 91(5), 1053-1075.

SEAP (Secretaria Especial de Aquicultura e Pesca). 2006. Aquicultura e pesca: desenvolvimento sustentável no Brasil. In: Caderno de Resoluções da $2^{a}$ Conferência Nacional de Aquicultura e Pesca. Brasília, Distrito Federal, Brazil, 14-16 March 2006. Brasília: SEAP, pp. 1-87.

SIDONE, O. J. G., HADDAD, E. A. \& MENA-CHALCO, J. P. 2016. Science in Brazilian regions: development of scholarly production and research collaboration networks. Transinformação, 24(2), 32-15.

SILVA, S. T., ANDRADE, D. A. \& MONT'ALVERNE, T. C. F. 2020. A invisibilidade das mulheres pescadoras no Brasil: uma discussão a partir dos Objetivos de Desenvolvimento Sustentável 5 e 14. Revista do Programa de Pós-Graduação em Direito da UFC, 40(1), 143-159.

SMITH, H. \& BASURTO, X. 2019. Defining small-scale fisheries and examining the role of science in shaping perceptions of who and what counts: a systematic review. Frontiers in Marine Science, 6, 236, DOI: https://doi.org/10.3389/fmars.2019.00236
SÖDERLUND, T. \& MADISON, G. 2015. Characteristics of gender studies publications: a bibliometric analysis based on a Swedish population database. Scientometrics, 105(3), 1347-1387.

SOUZA, S. R., RIBEIRO, N. S. \& MARTINEZ, S. A. 2019. Mulheres em comunidades pesqueiras no Brasil: um balanço da produção em teses e dissertações (2007-2017). In: MARTINEZ, S. A., HELLEBRANT, L. (orgs.). Mulheres na atividade pesqueira no Brasil [online]. Campos de Goyatacazes: EDUENF (Editora da Universidade Estadual do Norte Fluminense Darcy Ribeiro), pp. 9-19. Available at: https://www.funbio.org.br/ wp-content/uploads/2019/08/Mulheres_na_Atividade_ Pesqueira_no_Brasil.pdf [Accessed: 15 November 2021].

STAPLES, K. \& NATCHER, D. C. 2015. Gender, decision making, and natural resource co-management in Yukon. Arctic, 68(3), 356-366.

TANNENBAUM, C., ELLIS, R. P., EYSSEL, F., ZOU, J. \& SCHIEBINGER, L. 2019. Sex and gender analysis improves science and engineering. Nature, 575, 137-146.

VERMA, N. 2018. Integrating a gender perspective into the Blue Economy. In: ATTRI, V. N. \& BUHLER-MULLER, N. (orgs.). The blue economy handbook of the Indian Ocean region. South Africa: Africa Institute of South Africa, pp. 98-125.

VIDAL, M. F. \& GONÇALVES, M. F. 2008. O segmento da pesca extrativa marinha na costa do Nordeste. Informe Rural [online], 2(11), 1-17. Available at: https://www.bnb.gov.br/documents/80223/800705/ano2-11\%282\%29.pdf/ab097686-30cf-417b-ad25-af08517c0bdb [Accessed: 15 November 2021].

WARD-BATTS, J. 2008. Out of the wallet and into the purse: using micro data to test income pooling. Journal of Human Resources, 43(2), 325-351.

WESTERMANN, O., ASHBY, J. \& PRETTY, J. 2005. Gender and social capital: the importance of gender differences for the maturity and effectiveness of natural resource management groups. World Development, 33(11), 1783-1799.

WILLIAMS, M. J. 2008. Why look at fisheries through a gender lens?. Development, 51(2), 180-185.

WOODWARD, K. \& WOODWARD, S. 2015. Gender studies and interdisciplinarity. Palgrave Communications, 1, 15018.

WORM, B., ELLIFF, C., FONSECA, J. G., GELL, F. R., SERRA-GONÇALVES, C., HELDER, N. K., MURRAY, K. K., PECKHAM, H., PRELOVEC, L. \& SINK, K. 2021. Making ocean literacy inclusive and accessible. Ethics in Science and Environmental Politics, 21, 1-9.

WOUTERSE, F. 2016. The distribution of power and household behavior: evidence from Niger. IFPRI Discussion Paper 01548. Washington: IFPRI. 
SUPPLEMENTARY MATERIAL

\begin{tabular}{|c|c|c|c|c|c|c|c|}
\hline Reference & Title & Author(s) & Database & $\begin{array}{l}\text { Type of } \\
\text { publication }\end{array}$ & $\begin{array}{l}\text { Journal/ } \\
\text { University }\end{array}$ & $\begin{array}{l}\text { Year of } \\
\text { publication }\end{array}$ & Categories \\
\hline 1 & $\begin{array}{l}\text { Abordagens } \\
\text { alimentares em } \\
\text { uma comunidade } \\
\text { pesqueira de Cananéia, } \\
\text { Litoral Sul de São } \\
\text { Paulo: conhecimento } \\
\text { tradicional, gênero, } \\
\text { segurança alimentar e } \\
\text { sustentabilidade. }\end{array}$ & $\begin{array}{l}\text { Marina Vianna } \\
\text { Ferreira }\end{array}$ & Repomar & $\begin{array}{l}\text { Thesis/ } \\
\text { Dissertation }\end{array}$ & $\begin{array}{l}\text { Universidade } \\
\text { Federal de } \\
\text { São Carlos }\end{array}$ & 2007 & $\begin{array}{l}\text { Livelihood } \\
\text { Conservation } \\
\text { Participation }\end{array}$ \\
\hline 2 & $\begin{array}{l}\text { Pescadoras e } \\
\text { pescadores: a questão } \\
\text { da equidade de gênero } \\
\text { em uma reserva } \\
\text { extrativista marinha. }\end{array}$ & $\begin{array}{l}\text { Regina Célia Di } \\
\text { Ciommo }\end{array}$ & SCIELO & $\begin{array}{l}\text { Research } \\
\text { paper }\end{array}$ & $\begin{array}{l}\text { Ambiente e } \\
\text { Sociedade }\end{array}$ & 2007 & $\begin{array}{l}\text { Activism } \\
\text { Livelihood } \\
\text { Participation }\end{array}$ \\
\hline 3 & $\begin{array}{l}\text { As marisqueiras e a } \\
\text { reserva extrativista } \\
\text { Acaú-Goiana: uma } \\
\text { análise de práticas } \\
\text { participativas para } \\
\text { a conservação do } \\
\text { ambiente. }\end{array}$ & $\begin{array}{l}\text { Amanda } \\
\text { Braga de Melo } \\
\text { Fadigas }\end{array}$ & Repomar & $\begin{array}{l}\text { Thesis/ } \\
\text { Dissertation }\end{array}$ & $\begin{array}{l}\text { Universidade } \\
\text { Federal da } \\
\text { Paraíba / } \\
\text { Universidade } \\
\text { Estadual da } \\
\text { Paraíba }\end{array}$ & 2009 & $\begin{array}{l}\text { Activism } \\
\text { Knowledge } \\
\text { Livelihood } \\
\text { Conservation } \\
\text { Participation } \\
\text { Technology } \\
\text { Demographic }\end{array}$ \\
\hline 4 & $\begin{array}{l}\text { Lançando rede } \\
\text { tecida e retecida na } \\
\text { esperança de garantir } \\
\text { peixe e sonho: um } \\
\text { resgate das ações da } \\
\text { comissão pastoral } \\
\text { dos pescadores sobre } \\
\text { gênero, educação } \\
\text { e desenvolvimento } \\
\text { local na comunidade } \\
\text { de pescadores de } \\
\text { Itapissuma, PE. }\end{array}$ & $\begin{array}{l}\text { Gilmar Soares } \\
\text { Furtado }\end{array}$ & Repomar & $\begin{array}{l}\text { Thesis/ } \\
\text { Dissertation }\end{array}$ & $\begin{array}{l}\text { Universidade } \\
\text { Federal } \\
\text { Rural de } \\
\text { Pernambuco }\end{array}$ & 2010 & $\begin{array}{l} \\
\text { Activism } \\
\text { Livelihood } \\
\text { Participation } \\
\text { Technology }\end{array}$ \\
\hline 5 & $\begin{array}{l}\text { Mulher além da maré: } \\
\text { um experimento } \\
\text { cinematográfico } \\
\text { com as pescadoras } \\
\text { do município } \\
\text { de Itapissuma, } \\
\text { Pernambuco, na } \\
\text { tentativa de retratar } \\
\text { a realidade de } \\
\text { violência e os anseios } \\
\text { dessas mulheres } \\
\text { na perspectiva do } \\
\text { desenvolvimento local }\end{array}$ & $\begin{array}{l}\text { Silvana } \\
\text { Marques Porto } \\
\text { Araújo }\end{array}$ & $\begin{array}{l}\text { Catálogo } \\
\text { deTeses \& } \\
\text { Dissertações } \\
\text { CAPES }\end{array}$ & $\begin{array}{l}\text { Thesis/ } \\
\text { Dissertation }\end{array}$ & $\begin{array}{l}\text { Universidade } \\
\text { Federal } \\
\text { Rural de } \\
\text { Pernambuco }\end{array}$ & 2010 & $\begin{array}{l}\text { Activism } \\
\text { Livelihood } \\
\text { Demographic }\end{array}$ \\
\hline 6 & $\begin{array}{l}\text { Mulheres, } \\
\text { Manguezais e a } \\
\text { pesca no estuário do } \\
\text { Rio Mamanguape, } \\
\text { Paraíba }\end{array}$ & $\begin{array}{l}\text { Michelle da } \\
\text { Silva Pimentel } \\
\text { Rocha }\end{array}$ & Repomar & $\begin{array}{l}\text { Thesis/ } \\
\text { Dissertation }\end{array}$ & $\begin{array}{l}\text { Universidade } \\
\text { Federal da } \\
\text { Paraíba / } \\
\text { Universidade } \\
\text { Estadual da } \\
\text { Paraíba }\end{array}$ & 2010 & $\begin{array}{l}\text { Knowledge } \\
\text { Livelihood } \\
\text { Conservation } \\
\text { Participation } \\
\text { Technology } \\
\text { Demographic }\end{array}$ \\
\hline 7 & $\begin{array}{l}\text { Tipos de trabalho da } \\
\text { mulher na pesca do } \\
\text { litoral do Paraná }\end{array}$ & $\begin{array}{l}\text { Carolina de } \\
\text { Andrade Mello }\end{array}$ & Repomar & $\begin{array}{l}\text { Thesis/ } \\
\text { Dissertation }\end{array}$ & $\begin{array}{l}\text { Universidade } \\
\text { Federal do } \\
\text { Paraná }\end{array}$ & 2010 & $\begin{array}{l}\text { Livelihood } \\
\text { Participation } \\
\text { Technology }\end{array}$ \\
\hline
\end{tabular}


Continued. Supplementary Material

\begin{tabular}{|c|c|c|c|c|c|c|c|}
\hline 8 & $\begin{array}{l}\text { (Re) produção social } \\
\text { e dinâmica ambiental } \\
\text { no espaço da pesca: } \\
\text { reconstruindo a } \\
\text { territorialidade das } \\
\text { marisqueiras em } \\
\text { Taiçoca de Fora - Nossa } \\
\text { Senhora do Socorro / SE }\end{array}$ & $\begin{array}{l}\text { Eline Almeida } \\
\text { Santos }\end{array}$ & Repomar & $\begin{array}{l}\text { Thesis/ } \\
\text { Dissertation }\end{array}$ & $\begin{array}{l}\text { Universidade } \\
\text { Federal de } \\
\text { Sergipe }\end{array}$ & 2012 & $\begin{array}{l}\text { Activism } \\
\text { Knowledge } \\
\text { Livelihood } \\
\text { Conservation } \\
\text { Participation } \\
\text { Technology }\end{array}$ \\
\hline 9 & $\begin{array}{l}\text { Use of fishing } \\
\text { resources by women } \\
\text { in the Mamanguape } \\
\text { River Estuary, Paraíba } \\
\text { state, Brazil. }\end{array}$ & $\begin{array}{l}\text { Michelle S.P. } \\
\text { Rocha; Idalina } \\
\text { M.F.L. Santiago; } \\
\text { Creuza S. } \\
\text { Cortez; Priscila } \\
\text { M. Trindade; } \\
\text { José S. Mourão }\end{array}$ & SCIELO & $\begin{array}{l}\text { Research } \\
\text { paper }\end{array}$ & $\begin{array}{l}\text { Anais da } \\
\text { Academia } \\
\text { Brasileira de } \\
\text { Ciências }\end{array}$ & 2012 & $\begin{array}{l}\text { Knowledge } \\
\text { Livelihood } \\
\text { Participation } \\
\text { Demographic }\end{array}$ \\
\hline 10 & $\begin{array}{l}\text { Women participation } \\
\text { in the management } \\
\text { of a Marine Protected } \\
\text { Area in Brazil }\end{array}$ & $\begin{array}{l}\text { Regina C. } \\
\text { Di Ciommo; } \\
\text { Alexandre } \\
\text { Schiavetti }\end{array}$ & $\begin{array}{l}\text { Web of } \\
\text { Science }\end{array}$ & $\begin{array}{l}\text { Research } \\
\text { paper }\end{array}$ & $\begin{array}{l}\text { Ocean \& } \\
\text { Coastal } \\
\text { Management }\end{array}$ & 2012 & $\begin{array}{l}\text { Activism } \\
\text { Livelihood } \\
\text { Participation } \\
\text { Demographic }\end{array}$ \\
\hline 11 & $\begin{array}{l}\text { Diálogos entre gênero, } \\
\text { gestão e educação } \\
\text { ambiental: os papéis } \\
\text { das mulheres nos } \\
\text { modos de vida na } \\
\text { pesca artesanal }\end{array}$ & $\begin{array}{l}\text { Melina Chiba } \\
\text { Galvão }\end{array}$ & Repomar & $\begin{array}{l}\text { Thesis/ } \\
\text { Dissertation }\end{array}$ & $\begin{array}{l}\text { Universidade } \\
\text { Federal do Rio } \\
\text { Grande }\end{array}$ & 2013 & $\begin{array}{l}\text { Activism } \\
\text { Knowledge } \\
\text { Livelihood } \\
\text { Participation } \\
\text { Technology } \\
\text { Demographic }\end{array}$ \\
\hline 12 & $\begin{array}{l}\text { Mulheres e o mar: } \\
\text { uma etnografia } \\
\text { sobre pescadoras } \\
\text { embarcadas na pesca } \\
\text { artesanal no Litoral de } \\
\text { Santa Catarina, Brasil' }\end{array}$ & $\begin{array}{l}\text { Rose Mary } \\
\text { Gerber }\end{array}$ & $\begin{array}{l}\text { Catálogo de } \\
\text { Teses \& } \\
\text { Dissertações } \\
\text { CAPES }\end{array}$ & $\begin{array}{l}\text { Thesis/ } \\
\text { Dissertation }\end{array}$ & $\begin{array}{l}\text { Universidade } \\
\text { Federal de } \\
\text { Santa Catarina }\end{array}$ & 2013 & $\begin{array}{l}\text { Activism } \\
\text { Knowledge } \\
\text { Livelihood } \\
\text { Participation } \\
\text { Technology }\end{array}$ \\
\hline 13 & $\begin{array}{l}\text { Fisheries as a way } \\
\text { of life: Gendered } \\
\text { livelihoods, identities } \\
\text { and perspectives of } \\
\text { artisanal fisheries in } \\
\text { eastern Brazil }\end{array}$ & Anna N. Santos & $\begin{array}{l}\text { Web of } \\
\text { Science }\end{array}$ & $\begin{array}{l}\text { Research } \\
\text { paper }\end{array}$ & Marine Policy & 2015 & $\begin{array}{l}\text { Activism } \\
\text { Knowledge } \\
\text { Livelihood } \\
\text { Participation } \\
\text { Demographic }\end{array}$ \\
\hline 14 & $\begin{array}{l}\text { Perspectivas do } \\
\text { trabalho feminino } \\
\text { na pesca artesanal: } \\
\text { particularidades da } \\
\text { comunidade llha do } \\
\text { Beto, Sergipe, Brasil }\end{array}$ & $\begin{array}{l}\text { Mary Lourdes } \\
\text { Santana } \\
\text { Martins; } \\
\text { Ronaldo } \\
\text { Gomes Alvim }\end{array}$ & SCIELO & $\begin{array}{l}\text { Research } \\
\text { paper }\end{array}$ & $\begin{array}{l}\text { Boletim } \\
\text { do Museu } \\
\text { Paraense } \\
\text { Emílio Goeldi } \\
\text { | Ciências } \\
\text { humanas }\end{array}$ & 2016 & $\begin{array}{l}\text { Knowledge } \\
\text { Livelihood } \\
\text { Participation } \\
\text { Technology }\end{array}$ \\
\hline 15 & $\begin{array}{l}\text { Por que a pescadora } \\
\text { é marisqueira? } \\
\text { Identidade de gênero } \\
\text { no quilombo de São } \\
\text { Braz - Santo Amaro/ } \\
\text { Bahia }\end{array}$ & $\begin{array}{l}\text { Roseni } \\
\text { Santana } \\
\text { Jesus }\end{array}$ & $\begin{array}{l}\text { Catálogo } \\
\text { de Teses \& } \\
\text { Dissertações } \\
\text { CAPES }\end{array}$ & $\begin{array}{l}\text { Thesis/ } \\
\text { Dissertation }\end{array}$ & $\begin{array}{l}\text { Universidade } \\
\text { Federal do } \\
\text { Recôncavo da } \\
\text { Bahia }\end{array}$ & 2016 & $\begin{array}{l}\text { Activism } \\
\text { Knowledge } \\
\text { Livelihood } \\
\text { Conservation } \\
\text { Participation } \\
\text { Technology } \\
\text { Demographic }\end{array}$ \\
\hline 16 & $\begin{array}{l}\text { The process of } \\
\text { legal recognition } \\
\text { of artisanal fishing } \\
\text { women of Santa } \\
\text { Cartina and definition } \\
\text { of labor and social } \\
\text { security rights }\end{array}$ & $\begin{array}{l}\text { Vera Lucia da } \\
\text { Silva; Maria } \\
\text { do Rosario } \\
\text { de Fatima } \\
\text { Andrade Leitão }\end{array}$ & $\begin{array}{l}\text { Web of } \\
\text { Science }\end{array}$ & $\begin{array}{l}\text { Research } \\
\text { paper }\end{array}$ & $\begin{array}{l}\text { Revista } \\
\text { Gênero \& } \\
\text { Direito }\end{array}$ & 2016 & $\begin{array}{l}\text { Knowledge } \\
\text { Livelihood } \\
\text { Participation }\end{array}$ \\
\hline
\end{tabular}


Continued. Supplementary Material

\begin{tabular}{|c|c|c|c|c|c|c|c|}
\hline 17 & $\begin{array}{l}\text { Mulheres da Z3 - O } \\
\text { camarão que "come" } \\
\text { as mãos e outras } \\
\text { lutas: contribuições } \\
\text { para o campo de } \\
\text { estudos sobre gênero } \\
\text { e pesca }\end{array}$ & $\begin{array}{l}\text { Luceni } \\
\text { Medeiros } \\
\text { Hellebrandt }\end{array}$ & $\begin{array}{l}\text { Catálogo } \\
\text { de Teses \& } \\
\text { Dissertações } \\
\text { CAPES }\end{array}$ & $\begin{array}{l}\text { Thesis/ } \\
\text { Dissertation }\end{array}$ & $\begin{array}{l}\text { Universidade } \\
\text { Federal de } \\
\text { Santa Catarina }\end{array}$ & 2017 & $\begin{array}{l}\text { Activism } \\
\text { Knowledge } \\
\text { Livelihood } \\
\text { Conservation } \\
\text { Participation } \\
\text { Technology }\end{array}$ \\
\hline 18 & $\begin{array}{l}\text { Marisqueiras da } \\
\text { Bacia de Campos - } \\
\text { relações de gênero e } \\
\text { o trabalho da mulher } \\
\text { na pesca artesanal no } \\
\text { Rio de Janeiro }\end{array}$ & Rafaella Theis & $\begin{array}{l}\text { Catálogo } \\
\text { de Teses \& } \\
\text { Dissertações } \\
\text { CAPES }\end{array}$ & $\begin{array}{l}\text { Thesis/ } \\
\text { Dissertation }\end{array}$ & $\begin{array}{l}\text { Universidade } \\
\text { Estadual } \\
\text { do Norte } \\
\text { Fluminense } \\
\text { Darcy Ribeiro }\end{array}$ & 2018 & $\begin{array}{l}\text { Activism } \\
\text { Knowledge } \\
\text { Livelihood } \\
\text { Participation }\end{array}$ \\
\hline 19 & $\begin{array}{l}\text { Women participation } \\
\text { in artisanal fishery: an } \\
\text { exploratory research } \\
\text { in the Canto de Itaipu, } \\
\text { Niterói, Rio de Janeiro }\end{array}$ & $\begin{array}{l}\text { Davi Henrique } \\
\text { Xavier Branco; } \\
\text { Carioni } \\
\text { Rodrigues; } \\
\text { Marina Puertas } \\
\text { Freire; Sidney } \\
\text { Lianza }\end{array}$ & $\begin{array}{l}\text { Web of } \\
\text { Science }\end{array}$ & $\begin{array}{l}\text { Research } \\
\text { paper }\end{array}$ & $\begin{array}{l}\text { Revista } \\
\text { Tecnologia e } \\
\text { Sociedade }\end{array}$ & 2018 & $\begin{array}{l}\text { Activism } \\
\text { Livelihood } \\
\text { Participation }\end{array}$ \\
\hline
\end{tabular}




\section{Erratum}

In the article "Gender and small-scale fisheries in Brazil: insights for a sustainable development agenda", with DOI code number http://doi.org/10.1590/2675-2824069.21033mmda, published at Ocean and Coastal Research, 2021, v69(suppl):e21033:

\section{Where it was written:}

Mariana Martins de Andrade ${ }^{1, *(-)}$, Luciana Yokoyama Xavier ${ }^{1,2}{ }^{\infty}$, Natalia de Miranda Grilli1(®) Carina Costa de Oliveira ${ }^{1,3}$, Denise Almeida de Andrade ${ }^{4}{ }^{\oplus}$, Giovanna C. Barreto ${ }^{5}{ }^{\oplus}$, Luceni Hellebrandt ${ }^{6}{ }^{\oplus}$, Melina Chiba Galvão ${ }^{7}$, Solange Teles da Silva ${ }^{1,8}$, Tarin Cristino Frota Mont'Alverne ${ }^{9}$, Leandra Regina Gonçalves ${ }^{1,2,10}$

${ }^{1}$ Liga das Mulheres pelo Oceano

${ }^{2}$ Instituto Oceanográfico da Universidade de São Paulo (Praça do Oceanografico, 191 - Cidade Universitária - São Paulo - 05508-120 - SP - Brazil)

${ }^{3}$ Universidade de Brasília - Faculdade de Direito - Grupo de Estudos em Direito,Recursos Naturais e Sustentabilidade (Gern-UnB). (Campus Universitário Darcy Ribeiro - Asa Norte - Brasília - 70904-970 - DF - Brazil)

${ }^{4}$ Centro Universitário Christus - Campus Parque Ecológico (Rua Adolfo Gurgel, 133 - 3. andar - Fortaleza - 60190-180 - Brazil)

${ }^{5}$ Universidade Federal do Paraná (R. dos Funcionários, 1540 - Cabral - Curitiba - 82590-300 - PR - Brazil)

${ }^{6}$ Universidade Federal do Rio Grande - Laboratório Interdisciplinar MAReSS - (Av. Mal. Floriano Peixoto, 2236 - São Lourenço do Sul 96170-000 - RS - Brazil)

7 Universidade Federal de Pelotas - Programa de Pós-Graduação em Antropologia (Rua Alberto Rosa, 154 - sala 117 - Pelotas 96010-770 - RS - Brazil)

${ }^{8}$ Instituto Federal de Santa Catarina - Campus Itajaí (Av. Ver. Abrahão João Francisco, 3899 - Ressacada - Itajaí - 88307-303 - SC - Brazil)

${ }^{9}$ Universidade Presbiteriana Mackenzie - Faculdade de Direito da (Rua da Consolação, 896 PPGDPE - São Paulo - 01302-907 - SP - Brazil)

${ }^{10}$ Universidade Federal do Ceará - Faculdade de Direito (R. Meton de Alencar, s/n - Centro - Fortaleza - 60035-160 - CE - Brazil)

\section{Should read:}

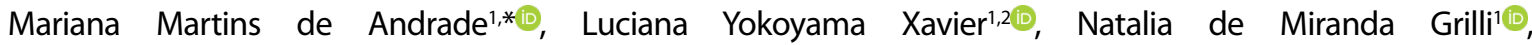

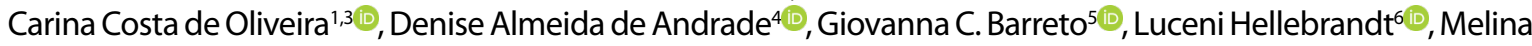
Chiba Galvão ${ }^{7}$, Solange Teles da Silva ${ }^{1,8}$, Tarin Cristino Frota Mont'Alverne ${ }^{9}$, Leandra Regina Gonçalves ${ }^{1,2,10}$

\footnotetext{
${ }^{1}$ Liga das Mulheres pelo Oceano

${ }^{2}$ Instituto Oceanográfico da Universidade de São Paulo (Praça do Oceanografico, 191 - Cidade Universitária - São Paulo - 05508-120 - SP - Brazil)

${ }^{3}$ Universidade de Brasília - Faculdade de Direito - Grupo de Estudos em Direito,Recursos Naturais e Sustentabilidade (Gern-UnB). (Campus Universitário Darcy Ribeiro - Asa Norte - Brasília - 70904-970 - DF - Brazil)

${ }^{4}$ Centro Universitário Christus - Campus Parque Ecológico (Rua Adolfo Gurgel, 133 - 3. andar - Fortaleza - 60190-180 - Brazil)

${ }^{5}$ Universidade Federal do Paraná (R. dos Funcionários, 1540 - Cabral - Curitiba - 82590-300 - PR - Brazil)

${ }^{6}$ Universidade Federal do Rio Grande - Laboratório Interdisciplinar MAReSS - (Av. Mal. Floriano Peixoto, 2236 - São Lourenço do Sul 96170-000 - RS - Brazil)

${ }^{7}$ Instituto Federal de Santa Catarina - Campus Itajaí (Av. Ver. Abrahão João Francisco, 3899 - Ressacada - Itajaí - $88307-303$ - SC - Brazil)

${ }^{8}$ Universidade Presbiteriana Mackenzie - Faculdade de Direito (Rua da Consolação, 896 PPGDPE - São Paulo - 01302-907 - SP - Brazil)

${ }^{9}$ Universidade Federal do Ceará - Faculdade de Direito (R. Meton de Alencar, s/n - Centro - Fortaleza - 60035-160 - CE - Brazil)

${ }^{10}$ Universidade Federal do Estado de São Paulo - Instituto do Mar ( Rua Silva Jardim, n 136 - Santos - 11015-020 - SP - Brazil)
} 